\title{
SPI ve CZI Kuraklık Indislerinin CBS Tabanlı Zamansal ve Konumsal Karşılaştırması: Burdur Gölü Havzası Örneği
}

\author{
Erhan Şener ${ }^{1, *} \oplus$, Şehnaz Şener ${ }^{2} \odot$ \\ ${ }^{1}$ Süleyman Demirel Üniversitesi, Uzaktan Algılama Arş. Uygulama Merkezi, Isparta. \\ 2Süleyman Demirel Üniversitesi, Mühendislik Fakültesi, Jeoloji Mühendisliği Bölümü, Isparta.
}

\section{Özet}

Son yıllarda su kaynakları üzerinde iklim değişikliğinin olumsuz etkileri daha fazla gözlenmeye başlamıştır. Burdur Gölü havzasında da yağışların azalmasına bağlı olarak özellikle yüzey sularında ciddi miktarlarda hacim kayıpları söz konusudur. Bu çalı̧̧mada, standartlaştırılmış yağış indeksi (SPI) ve Çin Z indeksi (CZI) yöntemleri kullanılarak havzaya yönelik kuraklık analizleri yapılmıștır. Bunun için havza içerisinde ve çevresinde bulunan 6 farkl meteoroloji istasyonuna ait yağıș verileri kullanılmıştır. Ayrıca SPI ve CZI indeksleri arasındaki ilișkiler istatistiksel olarak ortaya konulmuștur. Burdur Meteoroloji istasyonunda en uzun kuraklık döneminin 24 aylık zaman ölçeğinde SPI yöntem ile yapılan analizlerde 1612 gün ile 1951 yılının Ocak ayından itibaren yaşandığı, bununla birlikte en şiddetli kuraklığın ise 1989 yılının Ocak ayından itibaren 70.027 şiddetinde 2250 gün sürdüğü belirlenmiştir. Aynı meteoroloji istasyonunda Çin Z indeksi kullanılarak yapılan kuraklık analizlerine göre ise en uzun kuraklık dönemlerinin 1989 yllının Ocak ayından itibaren 70.782 şiddetinde 1553 gün sürdügü belirlenmiştir. Elde edilen sonuçlara göre 2019 yılında Burdur Gölü çevresi ile havzanın güneyinde orta ve hafif kuraklıklar tespit edilmiștir. Ayrıca her iki yöntemin $R^{2}$ değerleri (0.96-0.98) oldukça yüksek olup birbirlerine çok yakın indeks değerleri hesaplanmıștır.

\section{Anahtar Sözcükler}

Kuraklık Analizi, Standartlaştırılmış Yağış İndeksi (SPI), Çin Z İndeksi (CZI), Burdur Gölü Havzası

\section{GIS Based Spatiotemporal Comparation Between SPI and CZI Drought Index: A Case Study of Burdur Lake Basin}

\begin{abstract}
In recent years, the negative effects of climate change on water resources have been observed. Due to the decrease in precipitation in the Burdur Lake basin, there is serious volume loss especially in surface waters. In this study, basin drought analysis was performed using standardized precipitation index (SPI) and China Z index (CZI) methods. For this, precipitation data of 6 different meteorological stations located in and around the basin were used. In addition, the relationships between SPI and CZI indices are statistically revealed. In Burdur Meteorology station, it was determined that the longest drought period was experienced in the 24-month time scale with the SPI method since January 1951 with 1612 days. However, the most severe drought has been determined to have lasted 2250 days with a severity of 70.027 since January 1989. According to the drought analysis using the China $Z$ index at the same meteorology station, the longest drought periods were 1553 days since January 1989, with a severity of 70.782 . According to the obtained results, medium and mild droughts were detected around the Burdur Lake and south of the basin in 2019. In addition, the $R^{2}$ values of both methods (0.96-0.98) are quite high and very close index values were calculated.
\end{abstract}

\section{$\underline{\text { Keywords }}$}

Drought Analysis, Standardized Precipitation Index (SPI), China Z Index (CZI), Burdur Lake Basin

\section{Giriş}

Uluslararası Çölleşme ile Mücadele Sözleşmesine göre kuraklık; herhangi bir bölgede ölçülen yağışların, o bölgede kaydedilmiş ortalama yağışın önemli ölçüde altına düşmesi sonucunda arazi kullanımını ve su kaynaklarını olumsuz yönde etkileyen bir doğal afet olarak tanımlanmaktadır (WMO 1997; Dracup vd. 1980). İklimin doğal bir süreci olan kuraklık, yağmur ormanları da dahil olmak üzere dünyanın herhangi bir iklim rejiminde ortaya çıkabilir. Diğer doğal afetlere nazaran etkileri yaygın olmasının aksine hızları çok daha yavaştır (WMO 2016). Aynı zamanda, diğer doğal afetlere göre nispeten çok daha fazla insanı etkileyen kuraklığın dünya genelindeki yıllık maliyeti çok yüksektir (Wilhite 2000). Özellikle son yıllarda dünyada etkisini gittikçe arttırmasına rağmen, kuraklığın kapsamı henüz tam olarak anlaşılamamış ve etkileri yeterince değerlendirilememiştir. Bunun doğal sonucu olarak ta kuraklığın kesin tanımı yapılamamaktadır. Yapılan tanımlar mesleklere göre meteorolojik, hidrolojik, tarımsal, coğrafik veya endüstriyel, enerji üretimi, su temini, denizcilik, mesire yerleri bakımından olmaktadır (Şen 2001). 
Tarih boyunca çok sayıda ekonomik, çevresel ve sosyal zararlara neden olsa da, kuraklıkların tanımlanması, belirlenmesi ve izlenmesi oldukça zor olduğundan diğer meteorolojik olaylardan daha az ilgi görmüştür (Mishra ve Singh 2011). Genel olarak uzun bir zaman periyodunda yağışın belirgin bir şekilde normal değerlerinin altına düşmesi olarak tanımlanan kuraklığın, meteorolojik, hidrolojik, tarımsal ve sosyo-ekonomik olmak üzere 4 farklı türü bulunmaktadır (Wilhite ve Glantz 1985; Choi vd. 2013; Sırdaş ve Şen 2003; Orhan 2014; Mishra ve Singh 2011; Şener ve Şener 2019; Kömüşçü ve Erkan 2006). Meteorolojik Kuraklık genel olarak belirli bir bölgenin belli bir periyodun ortalamasına göre yağıŞ miktarının azalması veya belirli bir zaman periyoduna ait normallerde meydana gelen sapmalar olarak tanımlanmakta olup ilk görülen kuraklık türüdür (Anisfeld 2010). Hidrolojik kuraklık ise yağışlarda meydana gelen azalmaya bağlı olarak yüzey ve yeraltı sularındaki azalma olarak tanımlanmaktadır (Wilhite ve Glantz 1985; Tuna vd. 2009; Sırdaş 2002). Belirli bir zaman diliminde bitkilerin ihtiyacı olan toprak neminin yetersiz kalması ise tarımsal kuraklığı işaret eder.

Meteorolojik, hidrolojik ve tarımsal kuraklıktan kaynaklanabilecek olası etkilerin en aza indirilebilmesi kuraklıkların etkileyebileceği alanların yanı sıra, şiddeti ve süresine bağlı olarak gerekli planlamaların yapılarak kuraklığa hazırlıklı olmakla mümkündür (Mishra ve Singh 2011). Bu amaçla birçok araştırmacı ve kurum tarafından kuraklıkların izlenmesi amacıyla çok sayıda kuraklık indeksi geliştirilmiştir. Söz konusu kuraklık indekslerinden en önemlileri Standartlaştırılmış Yağış İndeksi (Mckee vd. 1993), Palmer Kuraklık İndeksi (Palmer 1965), Standart Yağış Buharlaşma İndeksi (Vicente Serrano vd. 2010), Normalin Yüzdesi İndeksi (Willeke vd. 1994), Keşif Kuraklık İndeksi (Tsakiris ve Vangelis 2005), Ondalıklar İndeksi (Gibbs ve Maher 1967), Standartlaştırılmış Akım İndeksi (Shukla ve Wood 1993), Standartlaştırılmış Yeraltısuyu İndeksi, Standartlaştırılmış Rezervuar İndeksi, China Z indeksi (Wu vd. 2001), Efektif Kuraklık İndeksi (Byun ve Wilhit 1999), Normalleştirilmiş Bitki Fark İndeksi (NDVI), Bitki Durum İndeksi (VCI)'dir. Söz konusu indekslerde yağış başta olmak üzere sıcaklık, potansiyel buharlaşma ve terleme en sık olarak kullanılan girdi parametrelerindendir. Aynı zamanda bazı indeks hesaplamalarında çok sayıda girdi parametresine ihtiyaç varken standartlaştırılmış yağış indeksi ve efektif kuraklık indeksi gibi bazı indekslerde ise sadece yağış verileri girdi olarak kullanılmaktadır. Bu yüzden söz konusu yağış verilerine nispeten kolay ulaşılabilmesi ve indeks hesaplamalarının basit ve tutarlı sonuçlarından dolayı standartlaştırılmış yağış indeksi dünya genelinde en sık kullanılan kuraklık indekslerinin başında gelmektedir.

Sırdaş ve Şen (2003), Trakya'nın (İstanbul, Edirne, Tekirdağ ve Kırklareli) kuraklık analizini SYİ metoduyla yapmışlardır. Çalışma alanı için farklı zaman ölçeklerinde seriler üretilmiş ve kriging yöntemiyle kuraklık haritaları hazırlanmıştır. Kuraklık süresi ve şiddeti arasındaki ilişkileri gösterebilmek için kurak dönem için kuraklık şiddeti ve SYİ değerleri hesaplanmıştır. Çaldağ vd. (2004) SYİ yöntemi ile Türkiye'nin kuzeybatısı (Trakya Bölgesi) için kuraklık analizi yapmışlardır. SYİ değerlerine göre Trakya Bölgesi, İstanbul hariç 2000 ve 2001 yıllarında şiddetli kuraklık etkisi altında kalmıştır. Pamuk vd. (2004) Ege bölgesindeki meteorolojik kuraklığın şiddeti ve süresini belirlemek amacıyla Standartlaştırılmış Yağış İndeksi yöntemini kullanmışlardır. Söz konusu analizlere göre, çalışma alanı kış dönemlerinde orta kurak sınırına yakın olmakla birlikte tüm ayların ortalama değerlerinin ise normal sınırlar içerisinde bulunduğu belirlenmiştir. Morid vd. (2006) tarafından İran'da yapılan ve yedi farklı kuraklık indekslerinin karşılaştırılmasını amaçlayan çalışmada SPI ve CZI indeksleri arasındaki ilişkinin belirlenmesi amacıyla yapılan lineer regresyon analizlerinde determinasyon katsayısı değerlerinin $\left(\mathrm{R}^{2}\right)$ 0.84-0.96 arasında değiştiği belirlenmiştir. Jain vd. (2015) tarafından yapılan Ken nehir havzasında farklı kuraklık indekslerinin karşılaştırılmasını amaçlayan çalışmada SPI, CZI, EDI, Z-Score, RD ve RDDI indeksleri arasında yüksek korelasyon belirlenmiş ve bununla birlikte özellikle 9-12 ay zaman ölçeklerindeki korelasyonun çok daha yüksek olduğu tespit edilmiştir. Awchi ve Kalyana (2017) tarafindan Irak'ın kuzey bölgesinde standartlaştırılmış yağış indeksi ve coğrafi bilgi sistemleri kullanılarak yapılan çalışmada geçen yüzyılın ortalarından itibaren hemen hemen her 10 yılda bir ciddi kuraklık yaşandığını belirlenmiştir. Wambua vd. (2018) tarafından Tana nehir havzasında standartlaştırılmış yağış indeksi ile efektif kuraklık indeksi gibi farklı kuraklık indeksleri kullanarak yapılan çalışmada SPI ve EDI ile elde edilen kuraklık verileri haritalandırılmıştır. Buna göre Tana nehir havzasının güneydoğu kesiminin daha kuraklığa eğilimli alanlar oldukları belirlenmiştir. İrvem ve Özbuldu (2019) tarafından Muğla bölgesinde Standartlaştırılmış Yağış İndeksi yöntemi kullanarak yapılan kuraklık analizi çalışmasında özellikle son 30 yıllık zaman diliminde kuraklığın görülme frekansının arttığı ve kuraklık görülen ay sayısının giderek arttığını belirlenmiştir. Şener ve Şener (2019) tarafından Çorak Gölü Havzasında Standartlaştırılmış Yağış İndeksi ve Coğrafi Bilgi Sistemleri kullanılarak yapılan çalışmaya göre 1982, 1984, 1993, 1995, 2005 ve 2016 yıllarında havzanın tamamında hafif kuraklık gözlenirken 1971, 1976, 1985, 1988, 1994, 1997 ve 2015 yıllarında hafif yağışlı bir dönem yaşandığı belirlenmiştir. Ayrıca 1989 yılında havzanın \% 9.1'inde çok aşırı kuraklık yaşanırken 2009 yılında ise havzanın \% 50.3'ünden aşırı yağışlı ve \%47.3'ünde ise çok şiddetli yağışlı bir dönem yaşandığı tespit edilmiştir. Dikici (2019) Asi Havzasında yapılan kuraklık analizlerinin sonucunda Asi havzası genelinde yıllık toplam yağışlarda \%95 güven düzeyinde istatistiksel olarak anlamlı olmasa da bir artış eğilimi olduğu görülmüştür. Yıllık ortalama sıcaklıklarda ise, hem alt havza hem havza bazlı bariz bir artış eğilimi olduğu belirlenmiştir. Bakanoğulları (2020a) tarafından Trakya bölgesinde yaklaşık $4.4 \mathrm{~km}^{2}$ 'lik Kumdere Havzasında yapılmış olan pilot çalışmada Standartlaştırılmış YağıŞ Evapotranspirasyon İndisi (SPEI) ile Standartlaştırılmış Yağış İndisi (SPI) ile karşılaştırılmıştır. Buna göre SPEI ve SPI İndeksleri arasındaki regresyon analizinde SPI ve SPEI kuraklık indeksleri arasında determinasyon katsayısını $\left(\mathrm{R}^{2}\right) 0.95$ olarak belirlenmiştir. 
Bakanoğulları (2020b) İstanbul-Büyükçekmece içme suyu havzasında yer alan Damlıca deresi havzasında $1982-2006$ yılları arasına ait meteorolojik veriler kullanılarak kuraklığın sıklığı ve şiddetinin Standartlaştırılmış Yağış Evapotranspirasyon İndisi (SPEI) ile belirlenmesi ve Standartlaştırılmış Yağış İndisi (SPI) ile karşılaştırmıştır. Buna göre söz konusu çalışmada 25 yıllık veri seti ile yıllık SPEI ve SPI İndeksleri arasındaki regresyon analizinde, ikinci derece polinoma göre yıllık SPI ve SPEI kuraklık indeksleri arasında determinasyon katsayısı ( $\left.\mathrm{R}^{2}\right) 0.977$ olarak belirlenmiştir.

Bu çalışma Burdur Gölü Havzasında Standartlaştırılmış Yağış İndisi ile Çin Z İndisleri kullanılarak 1, 3, 6, 12 ve 24 aylık zaman ölçeklerinde kuraklık analizi yapılmıştır. Yağış bazlı iki farklı indeks kullanılarak yapılan analizlerden elde edilen verilerin istatistiksel karşılaștırması yapılmış aynı zamanda söz konusu veriler Coğrafi Bilgi Sistemleri (CBS) ortamında enterpole edilerek havzaya ait kuraklık haritaları elde edilmiştir.

\section{Materyal ve Yöntem}

\section{1. Çalışma Alanı}

Burdur Gölü havzası kapalı havza özelliğinde olup Türkiye’nin güneybatısında, Göller Bölgesi içerisinde yer almaktadır. Güneybatı Anadolu'da 36 53"ve $37^{\circ} 50^{\circ}$ " kuzey enlemler ile $29^{\circ} 24^{\prime}$ ve $30^{\circ} 53$ ' doğu boylamları arasında yaklaşık 3264 $\mathrm{km}^{2}$ alana sahiptir (Şekil 1). Havzada Burdur, Yarışlı ve Karataş Gölleri, Karamanlı ve Karaçal Barajı ve birçok gölet bulunmaktadır. Çalışma alanındaki en önemli yüzey suyu olan Burdur Gölü $37^{\circ} 45^{\prime}$ kuzey enlemi $30^{\circ} 12^{\prime}$ doğu boylamında, mevcut durumda toplam $125.8 \mathrm{~km}^{2}$ lik bir yüzey alanına sahiptir. Burdur Gölü, Türkiye'nin en derin göllerinden biridir. Temmuz (2018) ölçümlerine göre gölün su kotu $840.50 \mathrm{~m}$, derinliği $59.53 \mathrm{~m}$, göl hacmi ise 4195 hm ${ }^{3}$ 'tür. Gölün uzunluğu 23.60 ve genişliği 8.16 km'dir. Gölün kuzeydoğusu ile güneybatısındaki düzlük alanlar ise 850 $1000 \mathrm{~m}$ arasında yer almaktadır. Yapısı bakımından tektonik bir göldür. Gölün kuzeydoğusu ve kuzeyi ovalarla çevrilidir. Doğusu ve kuzeybatısı ise hemen yükselen dağlarla sınırlanmıştır (TOB 2018). Burdur Gölü’nün beslenimi, göl alanına düşen yağışlar, göle ulaşan mevsimlik ve sürekli akarsular, akiferlerden yeraltısuyu akımı, boşalımı ise, buharlaşma ile olmaktadır. Gölü besleyen önemli akarsular gölün güneybatı ucundan giren Bozçay deresi, sırasıyla doğuya doğru Kravgaz, Kurna, Çerçin, Lengüme dereleri ve Keçiborlu yönünden gelen Adalar çayıdır. Bu akarsuların debileri oldukça düşük olup, büyük bir kısmı yazın kurumaktadır. Kapalı bir havzada yer alan gölün dışarıya akıntısı yoktur. Göl suları ciddi oranda tuzludur (Ataol 2010). 1994 yılında gölün yarısı (12.600ha), 1998 yılında ise tamamı (24.800 ha) Ramsar Sözleşmesi listesine dahil edilmiştir. Alan, 1998 yılında ise Kültür Bakanlığı tarafından I. Derece Doğal Sit Alanı da ilan edilmiştir. Burdur Gölü 1987 yılından bu yana hacminin \%40’ını kaybetmiştir. Bu süreçte göl seviyesinde 9.5 metrelik alçalma meydana gelmiş olup gölün yüzey alanı 1987 yılında $203 \mathrm{~km}^{2}$ iken günümüzde $125.8 \mathrm{~km}^{2}$ 'ye kadar gerilemiştir (TOB 2018).

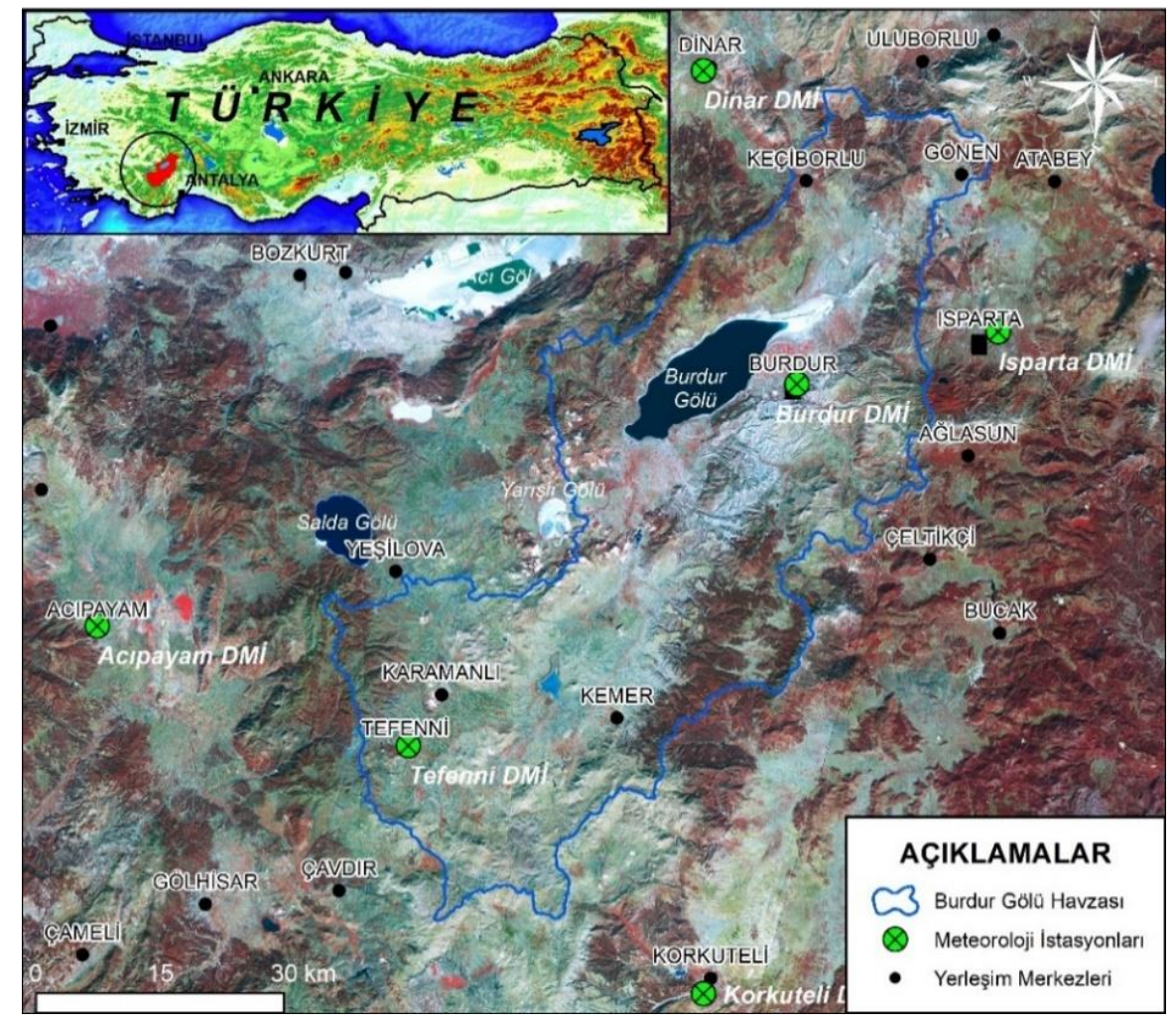

Şekil 1: Çalışma alanının yerbulduru haritası 


\subsection{Yöntem}

Burdur Gölü Havzasındaki kuraklıkların şiddeti, süresi ve alansal dağılımlarının belirlenmesi amacıyla Standartlaştırılmış Yağış İndeksi ile Çin Z İndeksi yöntemleri kullanılmıştır. Standartlaştırılmış Yağış İndeksi belirlenen zaman dilimi (1, 3, $6,9,12,24$ ve 48 ay) içinde aylık yağış miktarının, yağış serisinin ortalamasından olan farkının standart sapmaya bölünmesi ile elde edilir (McKee vd. 1993). Bu yöntemde en az 30 yıllık yağış kayıtları kullanılmaktadır. Yağış zaman serisi aylık toplam yağışlar şeklinde düzenlenerek hesaplamalar yapılmaktadır.

Standartlaştırılmış Yağış İndeksinde kuraklık sınıfları, standart normal (Gaussian) dağılımlı yağış verilerinden elde edilir. Dolayısıyla ilk aşamada ham yağış verilerinin olasılık dağılımının bulunması gerekir. Ancak yağış dizilerinin olasılık dağılım fonksiyonu genellikle normal dağılıma uymamaktadır (McKee vd. 1993; McKee vd. 1995). Yağış verilerine en iyi uyan olasılık dağılımı Gamma olasılık dağılımı olduğundan Standartlaştırılmış Yağış İndeksi yönteminde, yağış verilerinden elde edilen olasılık dağılım fonksiyonları Gamma olasılık dağılım fonksiyonlarına dönüştürülmektedir (Thom 1966; McKee vd. 1993; McKee vd. 1995).

$g(x)=\frac{1}{\beta^{\alpha} \Gamma(\alpha)} x^{\alpha-1} e^{x / \beta} \quad \mathrm{x}>0$ için

Burada;

$\Gamma(\alpha):$ Gamma Dağılımı

$\alpha$ : şekil parametresi $(\alpha>0)$

$\beta$ : ölçek parametresi $(\beta>0)$

$\mathrm{x}$ : yağış miktarını $(\mathrm{x}>0)$ ifade eder.

$\alpha$ ve $\beta$ ‘nın tahmininde maksimum olasılık çözümlerin kullanılır. Buna göre;

$\alpha=\frac{1}{4 A}\left(1+\sqrt{1+\frac{4 A}{3}}\right)$

$\beta=\frac{\bar{x}}{\alpha}$

$A=\ln (\bar{x})-\frac{\sum \ln (x)}{n}$

Burada n yağış gözlem sayısıdır. Eldeki mevcut verilerden elde edilen bu olasılık tanımlamaları daha sonra herhangi bir ayda gözlenmiş bir değerin kümülatif olasılığını bulmak için kullanılabilir. Bu durumda kümülatif olasılık aşağıdaki şekilde tanımlanır.

$G(x)=\int_{0}^{x} g(x) d x=\frac{1}{\beta^{\alpha} \Gamma(\alpha)_{0}} \int_{0}^{x} x^{\alpha-1} e^{-x / \beta_{d x}}$

Gamma fonksiyonu $\mathrm{x}=0$ için tanımsız olduğundan ve yağış dağılımı sıfır (0) değerler içerdiğinden kümülatif olasılık yeniden aşağıdaki şekilde tanımlanır.

$H(x)=q+(1-q) G x$

Bir sonraki aşamada, gamma dağılım fonksiyonundan elde edilen yağış olasılıkları, ters-standart normal dağılım fonksiyonu kullanılarak standart yağışlara dönüştürülür. Bu yolla ortalaması sıfır ve varyansı (değişkesi) bir olan standartlaştırılmış yağışlar elde edilir. Standart Yağış İndisi (SYI), belirlenen zaman dilimi içinde yağışın ortalamadan olan farkının standart sapmaya bölünmesi ile elde edilir (McKee vd. 1993).

$S Y I=\frac{X_{i}-\bar{X}_{i}}{\sigma}$

Burada;

SYI: Standartlaştırılmış Yağış İndeksi

$X_{i}$ : Yıllık yağış miktarının normalleştirilmiş miktarı,

$\bar{X}_{i}$ : Her bir istasyon için seçilen zaman aralığında yağış ortalaması,

$\sigma$ : Her bir istasyona ilişkin değerlerin zaman aralığı içindeki standart sapmasını ifade eder. 
Çin Z-indeksi (CZI), Çin Ulusal İklim Merkezi (NCC) tarafından ülke genelindeki kuraklık koşullarını izlemek için yaygın olarak kullanılmaktadır (Wu vd. 2001; Dogan vd. 2012). Çin Z-indeksinde, yağış verilerinin Pearson tip III dağılımına uygun olduğu ve Wilson-Hilferty küp kök dönüşümüyle (Wilson ve Hilferty 1931) ki-kare değişkenlerinin Z ölçeğinde ilişkili olduğu varsayılır ve şu şekilde hesaplanır (Kendall ve Stuart 1977).

$\sigma=\sqrt{\frac{1}{n}} \sum_{i=1}^{i i}\left(x_{i}-\bar{x}\right)^{2}$

$C_{s t}=\frac{\sum_{i=}^{n}\left(x_{i}-\bar{x}\right)^{3}}{n * \sigma^{3}}$

$C Z I=\frac{6}{C_{s t}}\left(\frac{C_{s t}}{2} Z S \operatorname{cor} e_{t}+1\right)^{1 / 3}-\frac{6}{C_{s t}}+\frac{C_{s t}}{6}$

Burada $C_{s t}$ herhangi t zaman ölçeği $(1,3,6,9,12$ ve 24 ay) için çarpıklık katsayısı, $\sigma$ standart sapma, n gözlem yapılan süredir. Her iki kuralık indekslerine ait kuraklık sınıfları Tablo 1'de verilmiştir.

Çalışma kapsamında kullanılan Standartlaştırılmış Yağış İndeksi ve Çin Z indeksi ile elde edilen veriler noktasal bazlı olup meteoroloji istasyonlarını temsil etmektedirler. Söz konusu veriler kullanılarak havza bazlı alansal tematik haritaların hazırlanmasında Ters Mesafe Ağırlıklı Enterpolasyon Yöntemi (Inverse Distance Weighted - IDW) kullanılmıştır. IDW enterpolasyon tekniği enterpole edilecek yüzeyde yakındaki noktaların uzaktaki noktalardan daha fazla ağırlığa sahip olması esasına dayandırılmıştır. Bu teknik enterpole edilecek noktadan uzaklaştıkça ağırlığı da azaltan ve örnekleme noktalarının ağırlıklı ortalamasına göre bir yüzey enterpolasyonu yapmaktadır (Köroğlu 2006; İlker vd. 2019).

Tablo 1: SPI ve CZI kuraklık indekslerinin kuraklık sınıfları

\begin{tabular}{|c|c|}
\hline Yağış (Kuraklık/Nemlilik) Sınıfı & Kuraklık İndeksleri \\
\hline Aşırı Yağışı & $\geq 2$ \\
\hline Çok Şiddetli Yağışlı & $1.50 / 1.99$ \\
\hline Orta Yağışlı & $1 / 1.49$ \\
\hline Hafif Yağışlı & $0 / 0.99$ \\
\hline Hafif Kuraklık & $0 /-0.99$ \\
\hline Orta Kuraklık & $-1 /-1.49$ \\
\hline Çok Şiddetli Kuraklık & $-1.49 /-1.99$ \\
\hline Aşırı Kuraklık & $\leq-2$ \\
\hline
\end{tabular}

\section{Araştırma Bulguları}

Burdur Gölü Havzasındaki meteorolojik kuraklık analizlerinde Standartlaştırılmış Yağıș İndeksi ile Çin Z İndeksi yöntemleri kullanılmıştır. Bu kapsamda havza içerisinde bulunan ve gerekli ölçüm periyotlarına sahip olan Burdur ve Tefenni meteoroloji istasyonlarının yanı sıra havzanın yakınlarında bulunan Dinar, Isparta, Korkuteli ve Acıpayam meteoroloji istasyonlarına ait yağış verileri kullanılmıştır. Burdur DMİ'de 1940, Tefenni DMİ'de 1964, Korkuteli DMİ'de 1969, Isparta DMİ'de 1940, Dinar DMİ'de 1959 ve Acıpayam DMİ'de ise 1697 yılından 2019 y1l Aralık ayını kapsayan veriler Devlet Meteoroloji İşleri Genel Müdürlüğü’nden temin edilerek kuraklık analizlerinde kullanılmıştır.

Burdur Meteoroloji İstasyonunda 1, 3, 6, 12 ve 24 aylık zaman ölçeklerinde standartlaştırılmış yağış indeksi yöntemi ile yapılan kuraklık analizlerine göre, en uzun kuraklık periyotlarının 1 aylık zaman ölçeğinde yapılan analizlerde 245 gün süre ile Haziran 2012'den, 3 aylık zaman ölçeğinde yapılan analizlerde 548 gün süre ile Nisan 2012'den, 6 aylık zaman ölçeğinde yapılan analizlerde 669 gün süre ile Aralık 1972'den, 12 aylık zaman ölçeğinde yapılan analizlerde 1247 gün süre ile Ocak 1972'den ve 24 aylık zaman ölçeğinde yapılan analizlerde ise 2250 gün süre ile Ocak 1989'dan itibaren yaşandığı belirlenmiştir. Bununla birlikte söz konusu meteoroloji istasyonunda en uzun yağışlı periyotların 1 aylık zaman ölçeğinde yapılan analizlerde 304 gün süre ile Ağustos 1968'den, 3 aylık zaman ölçeğinde yapılan analizlerde 428 gün süre ile Temmuz 1959'dan, 6 aylık zaman ölçeğinde yapılan analizlerde 519 gün süre ile Haziran 1975'den, 12 aylık zaman ölçeğinde yapılan analizlerde 1127 gün süre ile Aralık 2001'den ve 24 aylık zaman ölçeğinde yapılan analizlerde ise 1612 gün süre ile Ocak 1951'den itibaren yaşandıği tespit edilmiştir (Şekil 2). Çin Z indeksi kullanılarak yapılan kuraklık analizlerinde ise benzer sonuçlar elde edilmiştir (Şekil 2). 


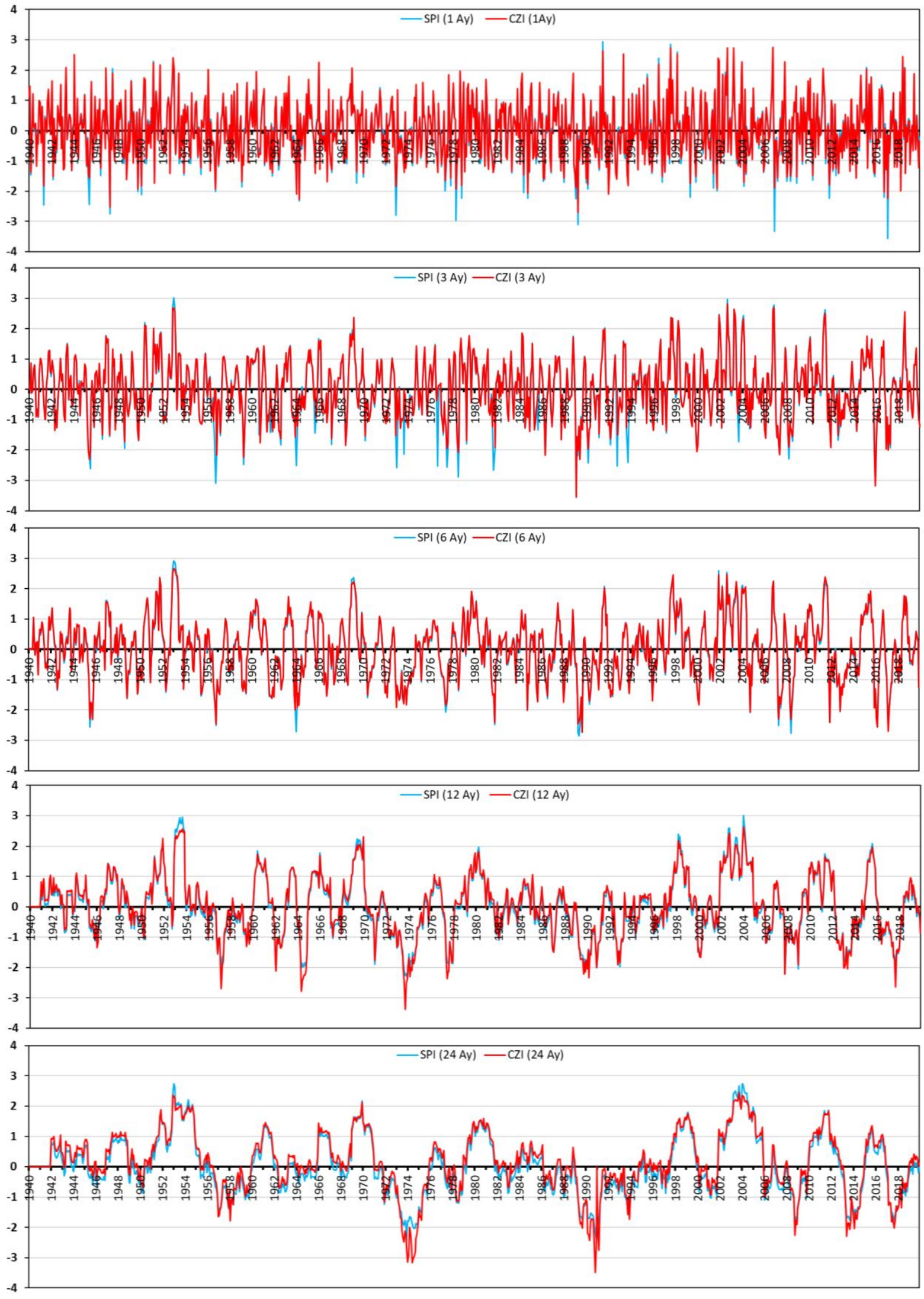

Şekil 2: Burdur Meteoroloji İstasyonunda 1, 3, 6, 12 ve 24 aylık zaman ölçeklerinde SPI ve CZI kuraklık indekslerinin karşılaştırması 
Burdur Meteoroloji istasyonunda standartlaştırılmış yağış indeksi ile yapılan kuraklık analizlerine göre en şiddetli kuraklık periyotlarının 1 aylık zaman ölçeğinde yapılan analizlerde182 gün süre ile 6.928 şiddetinde Aralık 2006'dan, 3 aylık zaman ölçeğinde yapılan analizlerde273 gün süre ile 13.644 şiddetinde Ocak 1989'dan, 6 aylık zaman ölçeğinde yapılan analizlerde 669 gün süre ile 25.963 şiddetinde Aralık 1972'den, 12 aylık zaman ölçeğinde yapılan analizlerde 1247 gün süre ile 48.7 şiddetinde Ocak 1972'den, 24 aylık zaman ölçeğinde yapılan analizlerde 2250 gün süre ile 70.027 şiddetinde Ocak 1989'dan itibaren yaşandığı belirlenmiştir. Burdur Meteoroloji istasyonunda Çin Z indeksi ile yapılan kuraklık analizlerine göre en şiddetli kuraklık periyotlarının 1 aylık zaman ölçeğinde yapılan analizlerde182 gün süre ile 5.742 şiddetinde Aralık 2006'dan, 3 aylık zaman ölçeğinde yapılan analizlerde 273 gün süre ile 14.478 şiddetinde Ocak 1989'dan, 6 aylık zaman ölçeğinde yapılan analizlerde 669 gün süre ile 26.167 şiddetinde Aralık 1972'den, 12 aylık zaman ölçeğinde yapılan analizlerde 1247 gün süre ile 50.512 şiddetinde Ocak 1972'den, 24 aylık zaman ölçeğinde yapılan analizlerde 1553 gün süre ile 70.782 şiddetinde Ocak 1989'dan itibaren yaşandı̆̆ belirlenmiştir.

Tefenni Meteoroloji İstasyonunda 1, 3, 6, 12 ve 24 aylık zaman ölçeklerinde standartlaştırılmış yağış indeksi yöntemi ile yapılan kuraklık analizlerine göre en uzun kuraklık periyotlarının 1 aylık zaman ölçeğinde yapılan analizlerde 304 gün süre ile Aralık 1988'den, 3 aylık zaman ölçeğinde yapılan analizlerde 577 gün süre ile Eylül 1973'den, 6 aylık zaman ölçeğinde yapılan analizlerde 1064 gün süre ile Ocak 1989'dan, 12 aylık zaman ölçeğinde yapılan analizlerde 1826 gün süre ile Mart 1989'dan ve 24 aylık zaman ölçeğinde yapılan analizlerde ise 2222 gün süre ile Aralık 1988'den itibaren yaşandığı belirlenmiştir. Bununla birlikte söz konusu meteoroloji istasyonunda en uzun yağışlı periyotların 1 aylık zaman ölçeğinde yapılan analizlerde 273 gün süre ile Ocak 1983 ve Eylül 1968'den, 3 aylık zaman ölçeğinde yapılan analizlerde 488 gün süre ile Temmuz 2014'den, 6 aylık zaman ölçeğinde yapılan analizlerde 577 gün süre ile Ocak 2009 'dan, 12 aylık zaman ölçeğinde yapılan analizlerde 1155 gün süre ile Şubat 2009'dan ve 24 aylık zaman ölçeğinde yapılan analizlerde ise 1796 gün süre ile Aralık 1965'den itibaren yaşandığı tespit edilmiştir (Şekil 3). Çin Z indeksi kullanılarak yapılan kuraklık analizlerinde ise benzer sonuçlar elde edilmiştir (Şekil 3).

Söz konusu meteoroloji istasyonunda en uzun yağışlı periyotların 1 aylık zaman ölçeğinde yapılan analizlerde 276 gün süre ile Mayıs 2014'den, 3 aylık zaman ölçeğinde yapılan analizlerde 549 gün süre ile Mayıs 2014'den, 6 aylık zaman ölçeğinde yapılan analizlerde 973 gün süre ile Kasım 2001'den, 12 aylık zaman ölçeğinde yapılan analizlerde 1370 gün süre ile Aralık 2001'den ve 24 aylık zaman ölçeğinde yapılan analizlerde ise 1492 gün süre ile Aralık 2001'den itibaren yaşandığı tespit edilmiştir (Şekil 4). Çin Z indeksi kullanılarak yapılan kuraklık analizlerinde ise benzer sonuçlar elde edilmiştir (Şekil 4).

Korkuteli Meteoroloji istasyonunda standartlaştırılmış yağış indeksi ile yapılan kuraklık analizlerine göre en şiddetli kuraklık periyotlarının 1 aylık zaman ölçeğinde yapılan analizlerde 243 gün süre ile 6,434 şiddetinde Aralık 1998'den, 3 aylık zaman ölçeğinde yapılan analizlerde 486 gün süre ile 15.23 şiddetinde Aralık 1989'dan, 6 aylık zaman ölçeğinde yapılan analizlerde 1095 gün süre ile 43.358 şiddetinde Aralık 1988'den, 12 aylık zaman ölçeğinde yapılan analizlerde 1216 gün süre ile 62.395 şiddetinde Şubat 1989'dan, 24 aylık zaman ölçeğinde yapılan analizlerde 1916 gün süre ile 73.474 şiddetinde Aralık 1988'den itibaren yaşandığ 1 belirlenmiştir. Korkuteli Meteoroloji istasyonunda Çin Z indeksi ile yapılan kuraklık analizlerine göre en şiddetli kuraklık periyotlarının 1 aylık zaman ölçeğinde yapılan analizlerde 304 gün süre ile 8.729 şiddetinde Aralık 1988'den, 3 aylık zaman ölçeğinde yapılan analizlerde 304 gün süre ile 14.05 şiddetinde Ocak 1989'dan, 6 aylık zaman ölçeğinde yapılan analizlerde 579 gün süre ile 18.468 şiddetinde Mayıs 1990'dan, 12 aylık zaman ölçeğinde yapılan analizlerde 851 gün süre ile 30.026 şiddetinde Kasım 1995'den, 24 aylık zaman ölçeğinde yapılan analizlerde 669 gün süre ile 24.178 şiddetinde Temmuz 1996'dan itibaren yaşandığ belirlenmiştir.

Isparta Meteoroloji İstasyonunda 1, 3, 6, 12 ve 24 aylık zaman ölçeklerinde standartlaştırılmış yağış indeksi yöntemi ile yapılan kuraklık analizlerine göre en uzun kuraklık periyotlarının 1 aylık zaman ölçeğinde yapılan analizlerde 153 gün süre ile Şubat 1970'den, 3 aylık zaman ölçeğinde yapılan analizlerde 488 gün süre ile Mayıs 1985'den, 6 aylık zaman ölçeğinde yapılan analizlerde 1003 gün süre ile Eylül 1984'den, 12 aylık zaman ölçeğinde yapılan analizlerde 1552 gün süre ile Aralık 1955'den ve 24 aylık zaman ölçeğinde yapılan analizlerde ise 3256 gün süre ile Şubat 1989'dan itibaren yaşandığ 1 belirlenmiştir. Bununla birlikte en uzun yağışlı periyotların 1 aylık zaman ölçeğinde yapılan analizlerde 304 gün süre ile Ağustos 1968'den, 3 aylık zaman ölçeğinde yapılan analizlerde 577 gün süre ile Ağustos 1968 'den, 6 aylık zaman ölçeğinde yapılan analizlerde 760 gün süre ile Haziran 1940'dan, 12 aylık zaman ölçeğinde yapılan analizlerde 1095 gün süre ile Aralık 1964'den ve 24 aylık zaman ölçeğinde yapılan analizlerde ise 3044 gün süre ile Eylül 1962'den itibaren yaşandığı tespit edilmiştir (Şekil 5). Çin Z indeksi kullanılarak yapılan kuraklık analizlerinde ise benzer sonuçlar elde edilmiştir (Şekil 5). Isparta Meteoroloji istasyonunda standartlaştırılmış yağış indeksi ile yapılan kuraklık analizlerine göre en şiddetli kuraklık periyotlarının 1 aylık zaman ölçeğinde yapılan analizlerde153 gün süre ile 6.489 şiddetinde Haziran 1993'den, 3 aylık zaman ölçeğinde yapılan analizlerde 396 gün süre ile 14.184 şiddetinde Mart 1970'den, 6 aylık zaman ölçeğinde yapılan analizlerde 911 gün süre ile 34.421 şiddetinde Ocak 1989'dan, 12 aylık zaman ölçeğinde yapılan analizlerde 1005 gün süre ile 44.537 şiddetinde Mart 1989'dan, 24 aylık zaman ölçeğinde yapılan analizlerde 3256 gün süre ile 100.356 şiddetinde Şubat 1989'dan itibaren yaşandığı belirlenmiştir. Isparta Meteoroloji istasyonunda Çin Z indeksi ile yapılan kuraklık analizlerine göre en şiddetli kuraklık periyotlarının 1 aylık zaman ölçeğinde yapılan analizlerde 273 gün süre ile 5.565 şiddetinde Aralık 1989'dan, 3 aylık zaman ölçeğinde yapılan analizlerde 427 gün süre ile 14.022 şiddetinde Aralık 1972'den, 6 aylık zaman ölçeğinde yapılan analizlerde 972 gün süre ile 28.505 şiddetinde Eylül 1984'den, 12 aylık zaman ölçeğinde yapılan analizlerde 1369 gün süre ile 31.87 şiddetinde Haziran 1956'dan, 24 
aylık zaman ölçeğinde yapılan analizlerde 3228 gün süre ile 95.386 şiddetinde Mart 1989'dan itibaren yaşandığ belirlenmiştir.
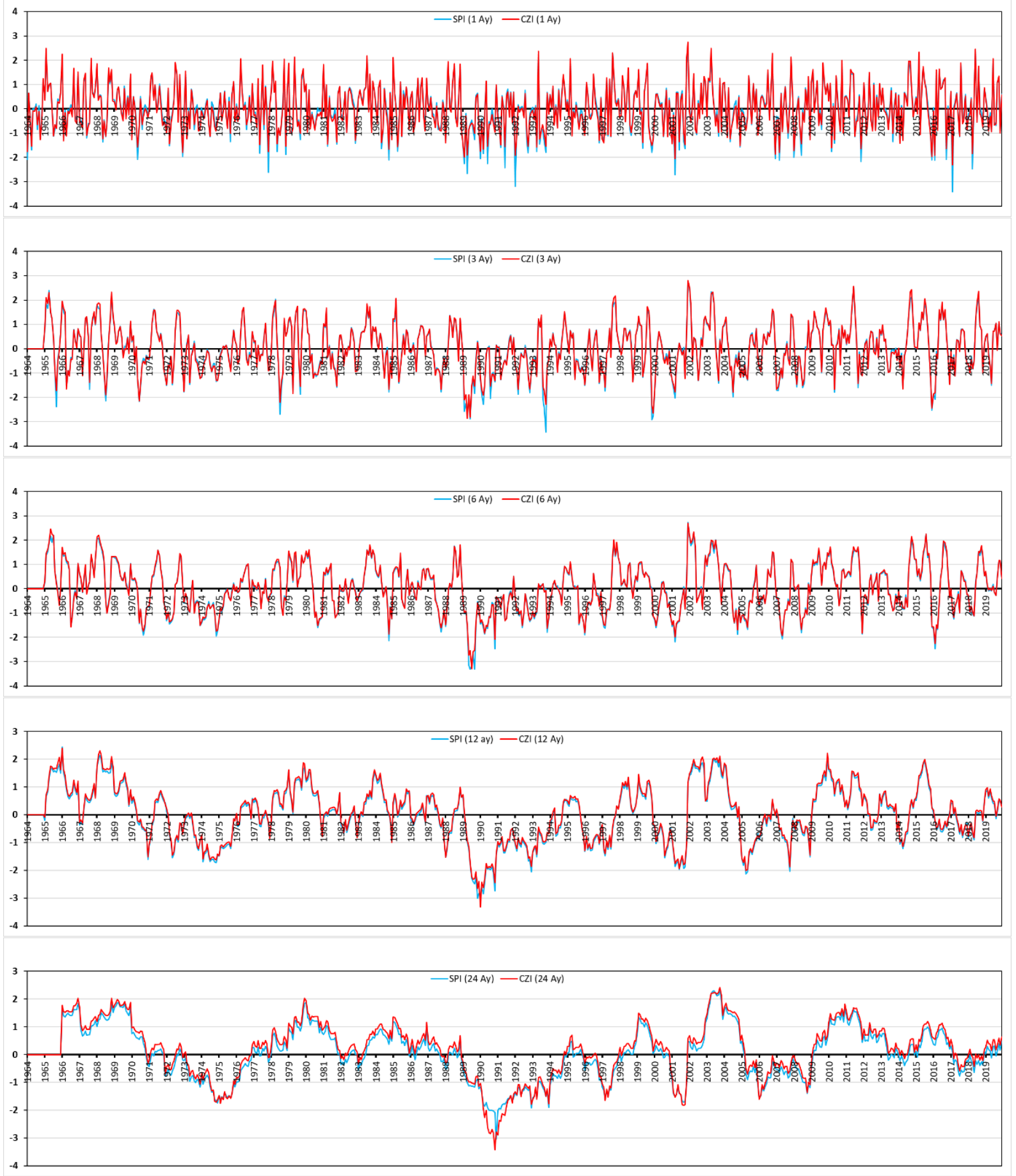

Şekil 3: Tefenni Meteoroloji İstasyonunda 1, 3, 6, 12 ve 24 aylık zaman ölçeklerinde SPI ve CZI kuraklık indekslerinin karşılaştırması 

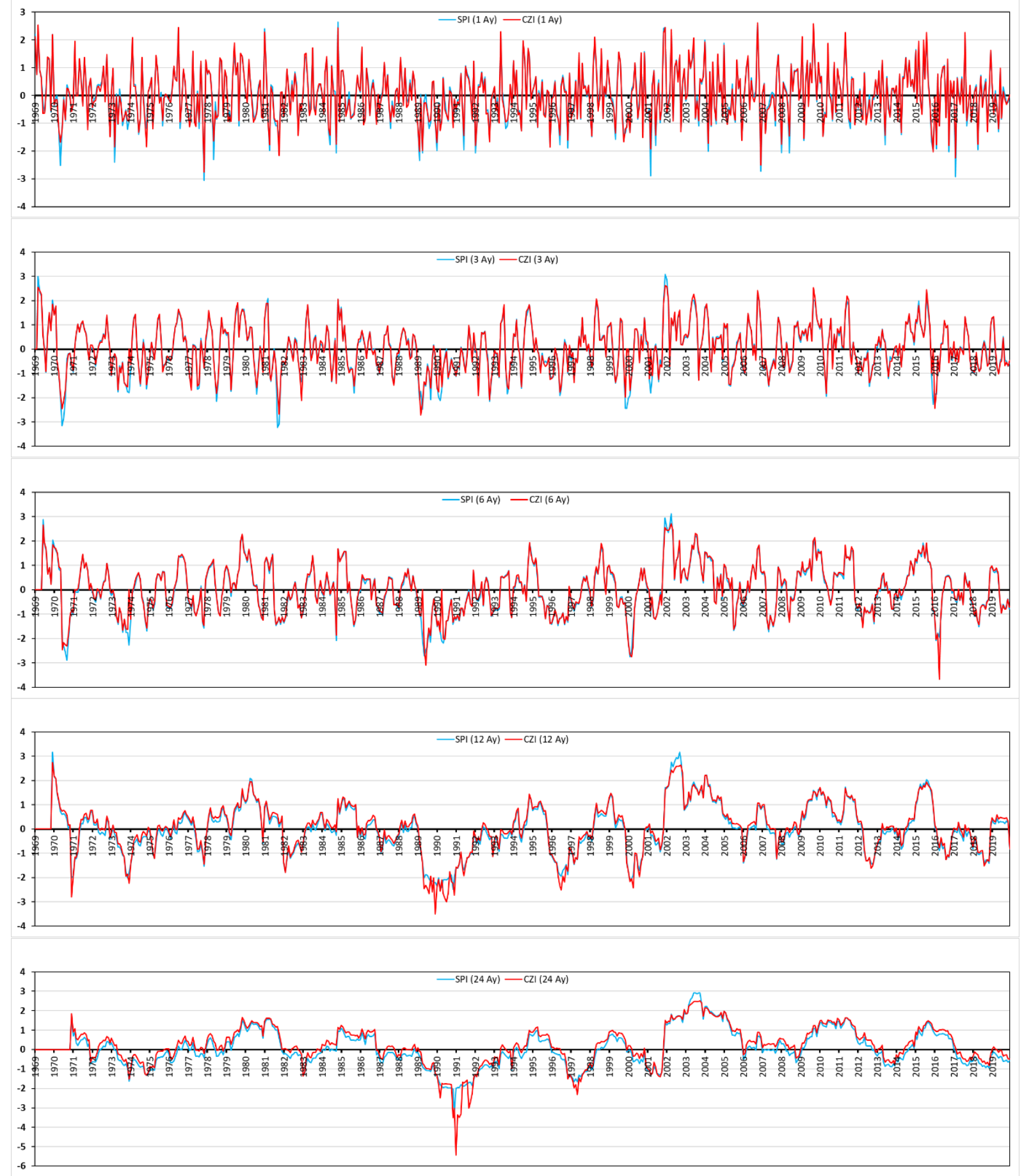

\section{Şekil 4: Korkuteli Meteoroloji Istasyonunda 1, 3, 6, 12 ve 24 aylık zaman ölçeklerinde SPI ve CZI kuraklık indekslerinin karşılaştırması}

Dinar Meteoroloji İstasyonunda 1, 3, 6, 12 ve 24 aylık zaman ölçeklerinde standartlaştırılmış yağış indeksi yöntemi ile yapılan kuraklık analizlerine göre en uzun kuraklık periyotlarının 1 aylık zaman ölçeğinde yapılan analizlerde 245 gün süre ile Haziran 2000'den, 3 aylık zaman ölçeğinde yapılan analizlerde 427 gün süre ile Temmuz 2000'den, 6 aylık zaman ölçeğinde yapılan analizlerde 1003 gün süre ile Eylül 1984'den, 12 aylık zaman ölçeğinde yapılan analizlerde 1461 gün süre ile Ocak1972'den ve 24 aylık zaman ölçeğinde yapılan analizlerde ise 2250 gün süre ile Ocak 1989'dan itibaren yaşandığı belirlenmiştir. Bununla birlikte söz konusu meteoroloji istasyonunda en uzun yağışlı periyotların 1 aylık zaman ölçeğinde yapılan analizlerde 275 gün süre ile Mart 2017'den, 3 aylık zaman ölçeğinde yapılan analizlerde 549 gün süre ile Mayıs 2014'den, 6 aylık zaman ölçeğinde yapılan analizlerde 609 gün süre ile Aralık 1967'den, 12 aylık zaman ölçeğinde yapılan analizlerde 1247 gün süre ile Ocak 2009'dan ve 24 aylık zaman ölçeğinde yapılan analizlerde ise 2679 
gün süre ile Ağustos 1963'den itibaren yaşandığı tespit edilmiştir (Şekil 6). Çin Z indeksi kullanılarak yapılan kuraklık analizlerinde ise benzer sonuçlar elde edilmiştir (Şekil 6).
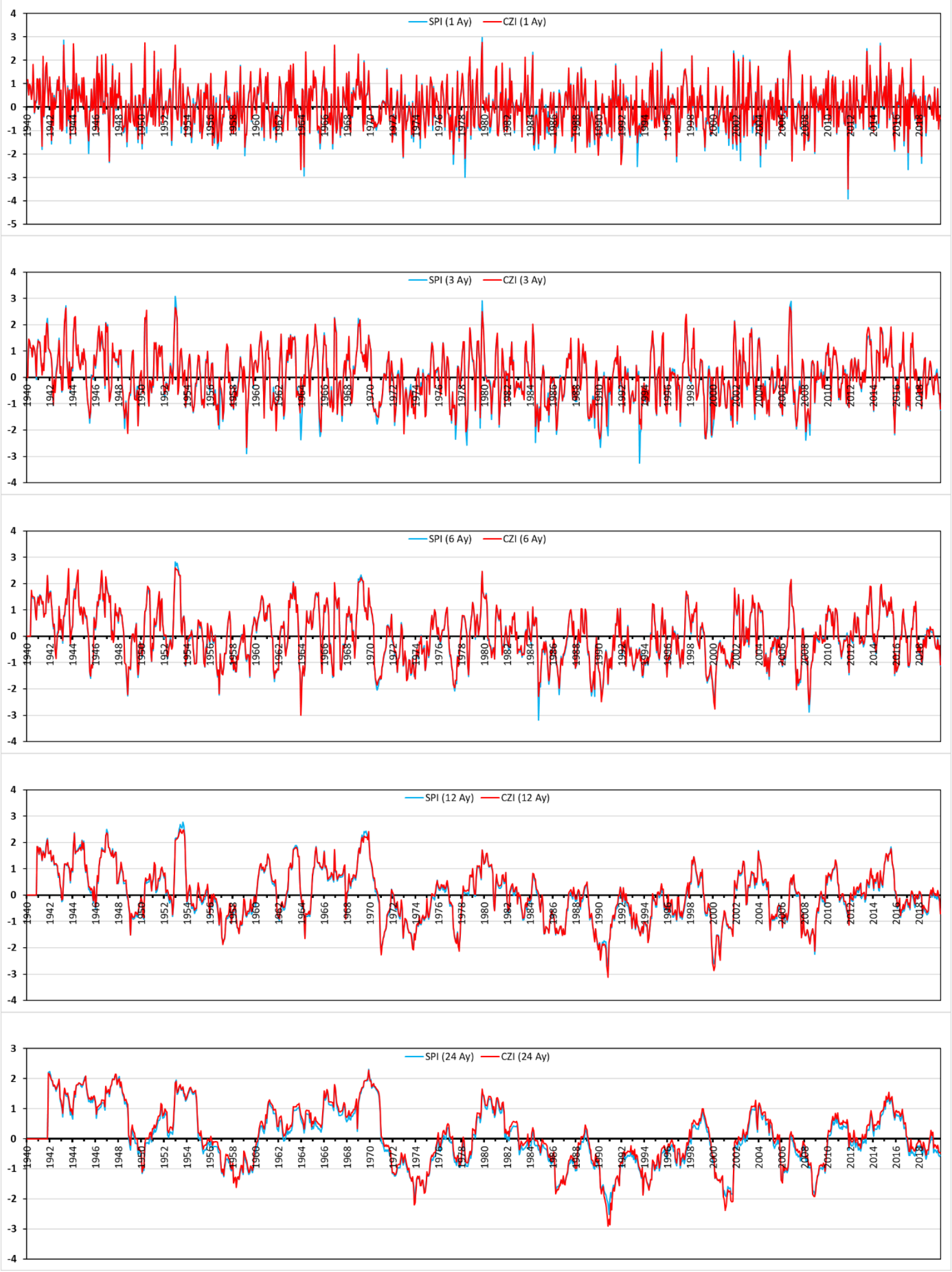

Şekil 5: Isparta Meteoroloji İstasyonunda 1, 3, 6, 12 ve 24 aylık zaman ölçeklerinde SPI ve CZI kuraklık indekslerinin karşılaştırması 

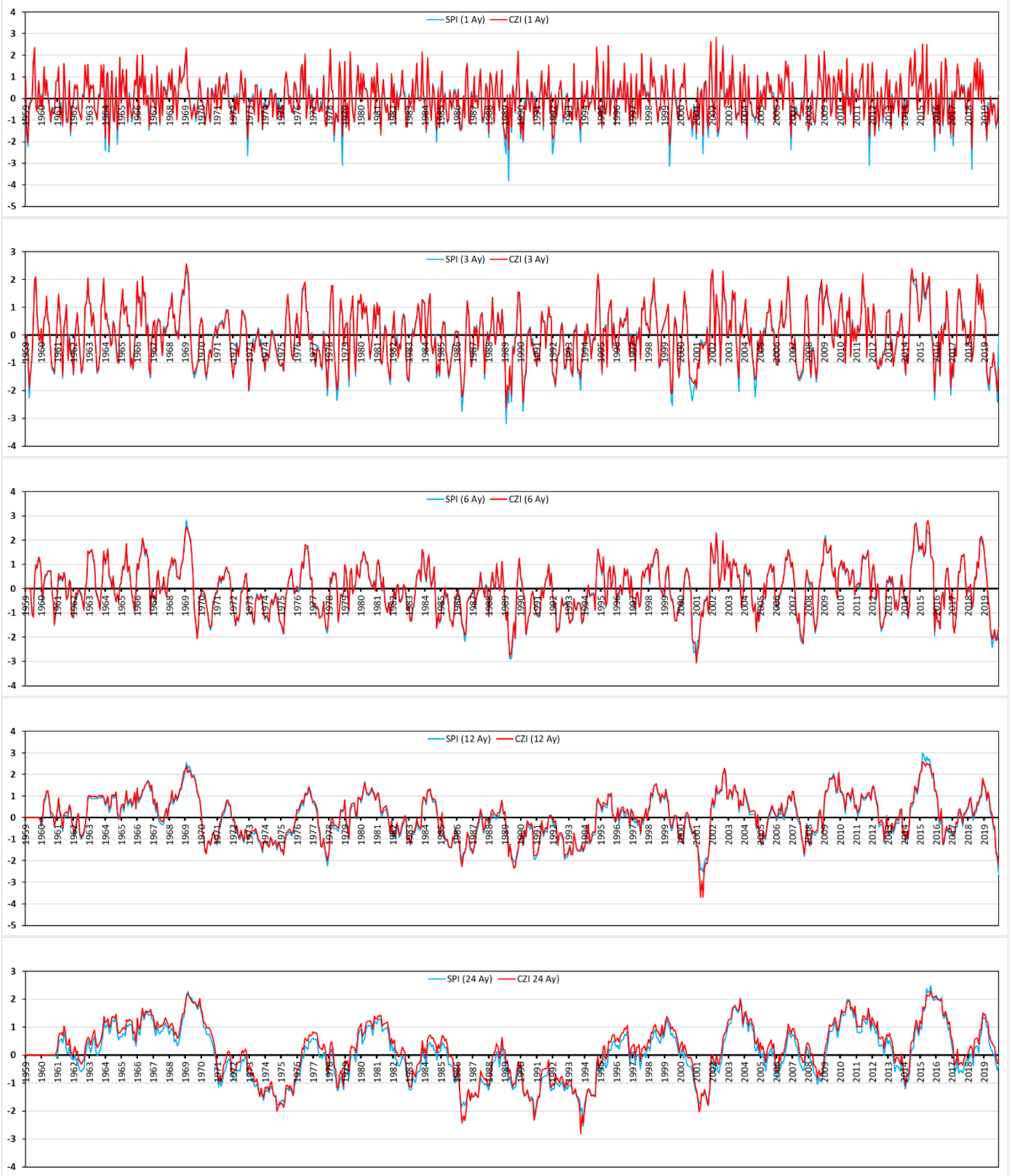

Şekil 6: Dinar Meteoroloji İstasyonunda 1, 3, 6, 12 ve 24 aylık zaman ölçeklerinde SPI ve CZI kuraklık indekslerinin karşılaştırması

Dinar Meteoroloji istasyonunda standartlaştırılmış yağış indeksi ile yapılan kuraklık analizlerine göre en şiddetli kuraklık periyotlarının 1 aylık zaman ölçeğinde yapılan analizlerde 245 gün süre ile 7.433 şiddetinde Haziran 2000'den, 3 aylık zaman ölçeğinde yapılan analizlerde 427 gün süre ile 16.107 şiddetinde Temmuz 2000'den, 6 aylık zaman ölçeğinde yapılan analizlerde 1003 gün süre ile 25.894 şiddetinde Eylül 1984'den, 12 aylık zaman ölçeğinde yapılan analizlerde 1461 gün süre ile 45.95 şiddetinde Ocak 1972'den, 24 aylık zaman ölçeğinde yapılan analizlerde 2250 gün süre ile 85.744 şiddetinde Ocak 1989'dan itibaren yaşandığ belirlenmiştir. Dinar Meteoroloji istasyonunda Çin Z indeksi ile yapılan kuraklık analizlerine göre en şiddetli kuraklık periyotlarının 1 aylık zaman ölçeğinde yapılan analizlerde 245 gün süre ile 7.143 şiddetinde Haziran 2000'den, 3 aylık zaman ölçeğinde yapılan analizlerde 427 gün süre ile 14.811 şiddetinde Temmuz 2000'den, 6 aylık zaman ölçeğinde yapılan analizlerde 912 gün süre ile 25.202 şiddetinde Aralık 1972 'den, 12 
aylık zaman ölçeğinde yapılan analizlerde 1492 gün süre ile 42.308 şiddetinde Aralık 1971'den, 24 aylık zaman ölçeğinde yapılan analizlerde 2219 gün süre ile 79.135 şiddetinde Şubat1989'dan itibaren yaşandığ belirlenmiştir.

Acıpayam Meteoroloji İstasyonunda 1, 3, 6, 12 ve 24 aylık zaman ölçeklerinde standartlaştırılmış yağgş indeksi yöntemi ile yapılan kuraklık analizlerine göre en uzun kuraklık periyotlarının 1 aylık zaman ölçeğinde yapılan analizlerde 275 gün süre ile Mart 1990'dan, 3 aylık zaman ölçeğinde yapılan analizlerde 546 gün süre ile Ocak 1990'dan, 6 aylık zaman ölçeğinde yapılan analizlerde 942 gün süre ile Şubat 1989'dan, 12 aylık zaman ölçeğinde yapılan analizlerde 2219 gün süre ile Şubat 1989'dan ve 24 aylık zaman ölçeğinde yapılan analizlerde ise 3622 gün süre ile May1s 1988 'den itibaren yaşandığı belirlenmiştir. Söz konusu meteoroloji istasyonunda en uzun yağışlı periyotların 1 aylık zaman ölçeğinde yapılan analizlerde 424 gün süre ile Ocak 2009'dan, 3 aylık zaman ölçeğinde yapılan analizlerde 485 gün süre ile Ocak 2009'dan, 6 aylık zaman ölçeğinde yapılan analizlerde 577 gün süre ile Ocak 2009'dan, 12 aylık zaman ölçeğinde yapılan analizlerde 1096 gün süre ile Aralık 2001'den ve 24 aylık zaman ölçeğinde yapılan analizlerde ise 1551 gün süre ile Aralık 1968'den itibaren yaşandığı tespit edilmiştir (Şekil 7). Çin Z indeksi kullanılarak yapılan kuraklık analizlerinde ise benzer sonuçlar elde edilmiştir.
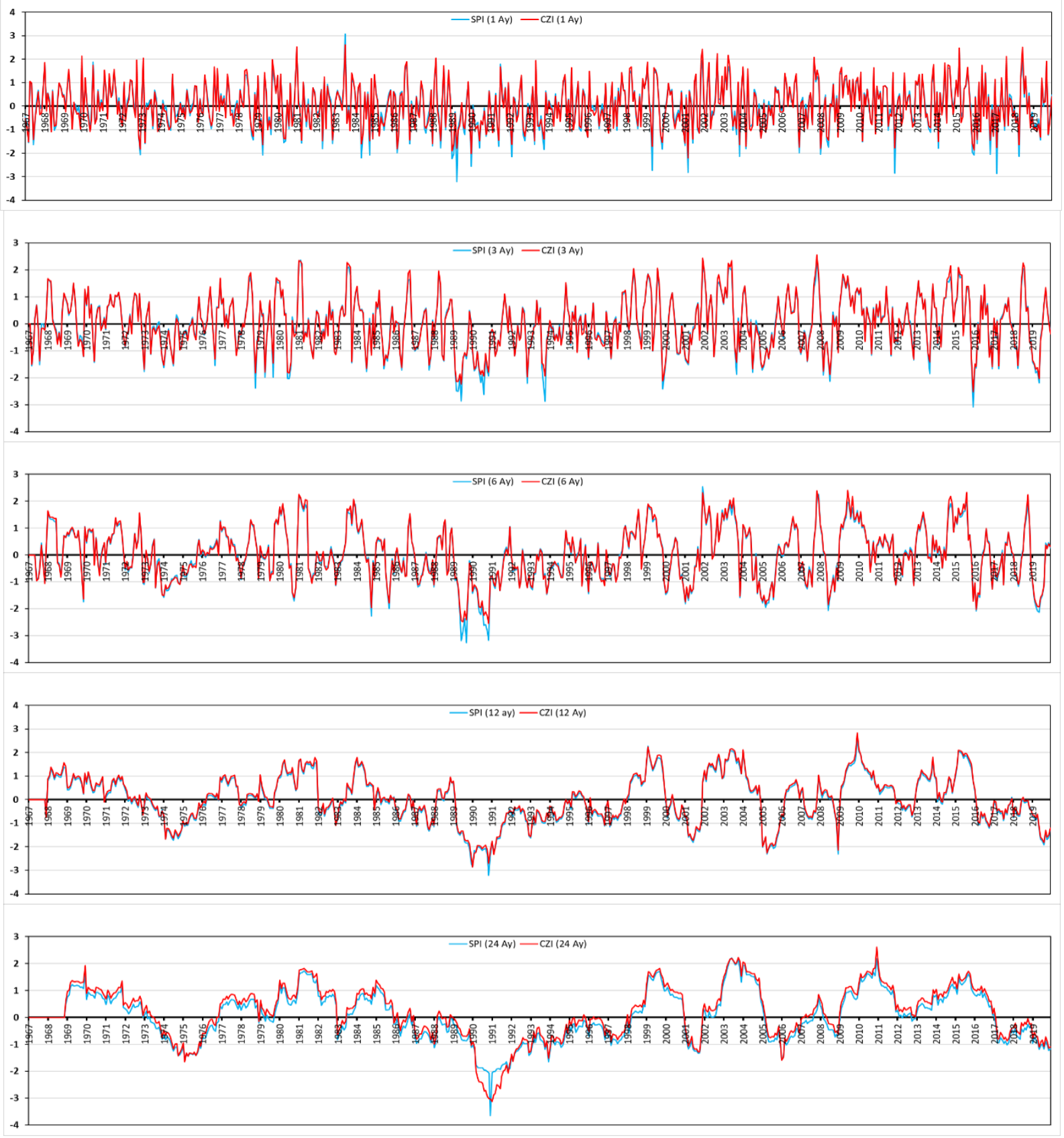

Şekil 7: Acıpayam Meteoroloji İstasyonunda 1, 3, 6, 12 ve 24 aylık zaman ölçeklerinde SPI ve CZI kuraklık indekslerinin karşılaştırması 
Acıpayam Meteoroloji istasyonunda standartlaştırılmış yağış indeksi ile yapılan kuraklık analizlerine göre en şiddetli kuraklık periyotlarının 1 aylık zaman ölçeğinde yapılan analizlerde 181 gün süre ile 9.148 şiddetinde Ocak 1989'dan, 3 aylık zaman ölçeğinde yapılan analizlerde 546 gün süre ile 23.175 şiddetinde Ocak 1990'dan, 6 aylık zaman ölçeğinde yapılan analizlerde 942 gün süre ile 49.798 şiddetinde Şubat 1989'dan, 12 aylık zaman ölçeğinde yapılan analizlerde 2219 gün süre ile 86.186 şiddetinde Şubat 1989'dan, 24 aylık zaman ölçeğinde yapılan analizlerde 3622 gün süre ile 111.107 şiddetinde Mayıs 1988'den itibaren yaşandığı belirlenmiştir. Acıpayam Meteoroloji istasyonunda Çin Z indeksi ile yapılan kuraklık analizlerine göre en şiddetli kuraklık periyotlarının 1 aylık zaman ölçeğinde yapılan analizlerde 365 gün süre ile 10.748 şiddetinde Aralık 1989'dan, 3 aylık zaman ölçeğinde yapılan analizlerde 608 gün süre ile 21.507 şiddetinde Aralık 1989'dan, 6 aylık zaman ölçeğinde yapılan analizlerde 942 gün süre ile 43.909 şiddetinde Şubat 1989'dan, 12 aylık zaman ölçeğinde yapılan analizlerde 2071 gün süre ile 80.343 şiddetinde Mart 1989'dan, 24 aylık zaman ölçeğinde yapılan analizlerde 2464 gün süre ile 95.562 şiddetinde Ocak 1989' dan itibaren yaşandığı belirlenmiştir.

\subsection{SPI ve CZI kuraklık indekslerinin karşılaştırması}

Çalışma alanındaki meteoroloji istasyonlarına ait veriler kullanılarak standartlaştırılmış yağış indeksi ile Çiz Z indeksi yöntemleri ile yapılan kuraklık analizleri sonucunda elde edilen indeks değerleri arasındaki ilişkilerin belirlenebilmesi amacıyla çeşitli istatistiksel analizler yapılmıştır. Bu kapsamda lineer regresyon analizlerine göre 1 ay zaman ölçeğinde SPI ve CZI indekslerinin değerleri arasındaki determinasyon katsayıları (R²) Burdur DMİ'de 0.9804; Tefenni DMI'de 0.9705; Korkuteli DMİ'de 0.9771; Isparta DMI' de 0.9843; Dinar DMI'de 0.9642 ve Acıpayam DMI'de ise 0.9586 olarak belirlenmiştir (Şekil 8).

Söz konusu $\mathrm{R}^{2}$ değerleri oldukça yüksek olup indeks değerlerinin birbirlerine çok yakın olduklarını göstermektedir. Meteoroloji istasyonlarına ait SPI ve CZI indeks değerleri arasındaki korelasyonların belirlenmesi amacıyla yapılan istatistiksel analizlere göre korelasyon katsayıları Burdur DMI'de 0.9901; Tefenni DMİ'de 0.9851; Korkuteli DMI'de 0.9885; Isparta DMI'de 0.9821; Dinar DMI'de 0.9820 ve Acıpayam DMİ'de ise 0.979'dir. Buna göre tüm istasyonlarda SPI ve CZI indeks değerleri arasında çok yüksek pozitif korelasyon olduğu tespit edilmiştir (Tablo 2). Meteoroloji istasyonlarına ait istatistiksel veriler incelendiğinde tüm meteoroloji istasyonlarında SPI ve CZI indeks değerlerinin özellikle ortalamalarının birbirlerine çok yakın olduğu ancak en büyük ve en küçük indeks değerleri arasında bir miktar değişim olduğu belirlenmiştir (Tablo 2).

SPI ve CZI yöntemleri ile elde edilen kuraklık indeks değerleri noktasal bazlı olup her bir veri ilgili meteoroloji istasyonunu temsil etmektedir. Söz konusu noktasal veriler kullanılarak alan bazlı tematik kuraklık haritaların oluşturulabilmesi amacıyla Coğrafi Bilgi Sistemleri ortamında enterpole edilmiştir. Bu kapsamda ArcGIS yazılımında IDW enterpolasyon yöntemi kullanılarak Burdur Gölü Havzasına ait kuraklık haritaları hazırlanmıştır (Şekil 9). En güncel durumun ortaya konulabilmesi amacıyla 2019 yılına ait 1 aylık zaman ölçeğinde SPI ve CZI yöntemleri kullanılarak hazırlanan kuraklık haritaları Şekil 9'da verilmiştir. Hazırlanan haritalarda negatif değerler kuraklığı işaret etmekte olup değer azaldıkça (yeşilden kırmızıya doğru) kuraklık şiddeti artmaktadır. Buna göre, Şubat ayında Burdur Gölü çevresinde orta kuraklık görülürken, Mart ayında SPI yöntemi ile gölün kuzeybatısında orta kuraklık belirlenmiştir. Haziran ayında ise kuzey kesimlerde genellikle hafif kuraklıklar görülmektedir. Temmuz ayında güney kesimlerde, Ağustos ayında ise güney kesimlerde ve göl çevresinde hafif kuraklıklar belirlenmiştir. Çalışma alanının kuzey kesimlerinde Eylül ayında hafif, Ekim ayında ise orta kuraklıklar gözlenmektedir. Genel olarak göl çevresinde Kasım ayında orta kuraklık, Aralık ayında ise hafif kuraklık hakimdir. Söz konusu haritalarda kuraklığın zamansal ve konumsal değişimleri incelendiğinde SPI ve CZI yöntemleri ile elde edilen haritaların birbirlerine çok uyumlu olduğu görülmektedir. 


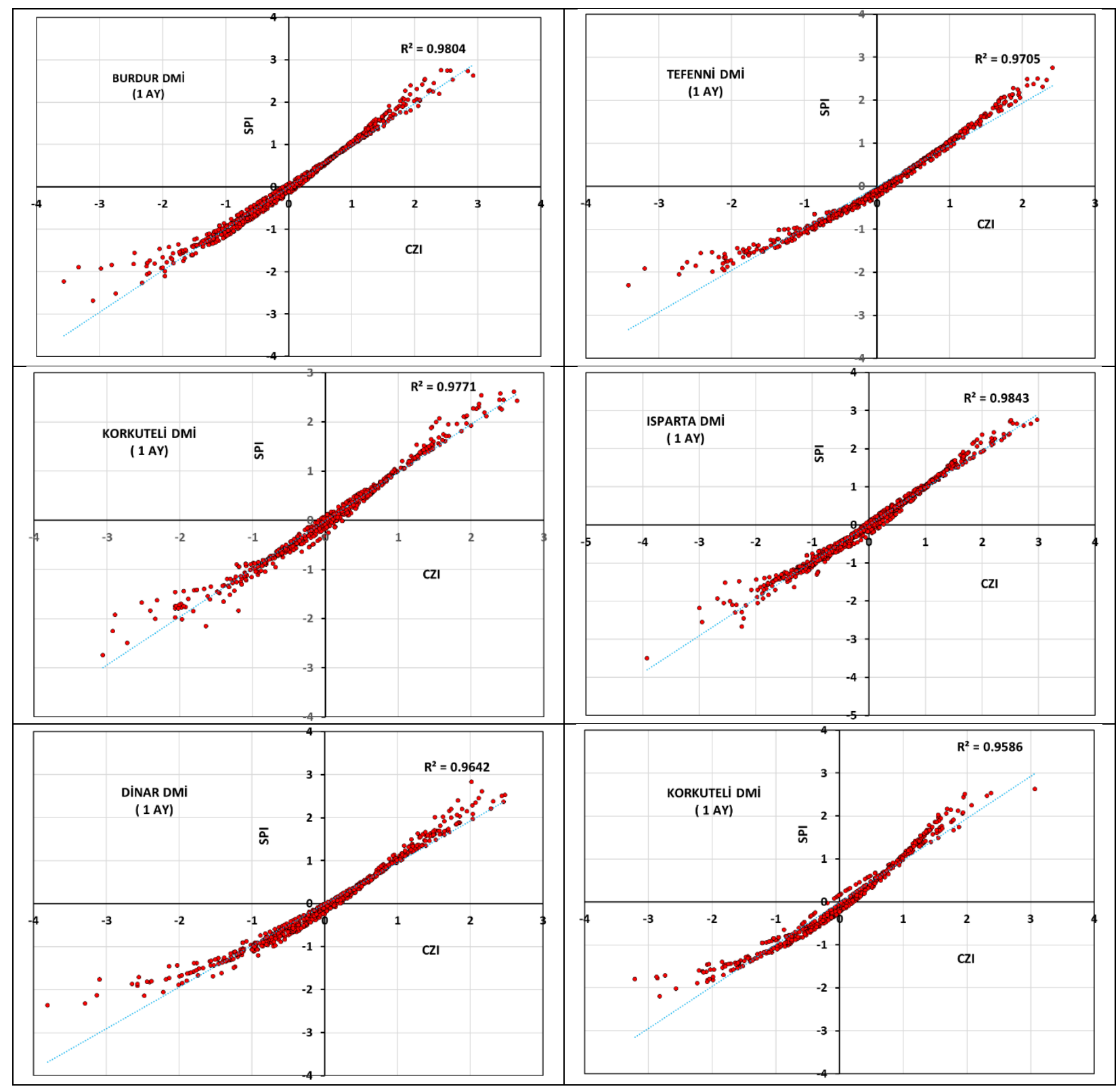

Şekil 8: Çalışmada kullanılan meteoroloji istasyonlarında 1 aylık zaman ölçeğindeki SPI ve CZI indeksleri arasındaki ilişki

Tablo 2: Çalışmada kullanılan meteoroloji istasyonlarında 1 aylık zaman ölçeğindeki SPI ve CZI indekslerine ait bazı istatistiksel veriler

\begin{tabular}{|c|c|c|c|c|c|c|c|c|c|c|c|c|}
\hline & \multicolumn{2}{|c|}{$\begin{array}{c}\text { BURDUR } \\
\text { DMII }\end{array}$} & \multicolumn{2}{|c|}{$\begin{array}{l}\text { TEFENNİ } \\
\text { DMII }\end{array}$} & \multicolumn{2}{|c|}{$\begin{array}{c}\text { KORKUTLI } \\
\text { DMİ }\end{array}$} & \multicolumn{2}{|c|}{$\begin{array}{c}\text { ISPARTA } \\
\text { DMI }\end{array}$} & \multicolumn{2}{|c|}{$\begin{array}{c}\text { DİNAR } \\
\text { DMII }\end{array}$} & \multicolumn{2}{|c|}{$\begin{array}{c}\text { ACIPAYAM } \\
\text { DMİ }\end{array}$} \\
\hline & SPI & CZI & SPI & CZI & SPI & CZI & SPI & CZI & SPI & CZI & SPI & CZI \\
\hline En Büyük & 2.9330 & 2.7530 & 2.4180 & 2.7480 & 2.6360 & 2.6120 & 2.9750 & 2.7570 & 2.4810 & 2.8250 & 3.0710 & 2.6200 \\
\hline En Küçük & -3.564 & -2.689 & -3.412 & -2.307 & -3.052 & -2.750 & -3.919 & -3.500 & -3.804 & -2.367 & -3.210 & -2.205 \\
\hline Ortalama & 0.0231 & 0.0186 & 0.0267 & 0.0140 & 0.0293 & 0.0239 & 0.0173 & 0.0256 & 0.0247 & 0.0164 & 0.0307 & 0.0198 \\
\hline $\begin{array}{l}\text { Standart } \\
\text { Sapma }\end{array}$ & 0.9696 & 0.9631 & 0.9705 & 0.9581 & 0.9625 & 0.9536 & 0.9756 & 0.9559 & 0.9732 & 0.9579 & 0.9621 & 0.9604 \\
\hline $\begin{array}{c}\text { Korelasyon } \\
\text { Katsayısı }\end{array}$ & \multicolumn{2}{|c|}{0.9901} & \multicolumn{2}{|c|}{0.9851} & \multicolumn{2}{|c|}{0.9885} & \multicolumn{2}{|c|}{0.9921} & \multicolumn{2}{|c|}{0.9820} & \multicolumn{2}{|c|}{0.9791} \\
\hline $\begin{array}{c}\text { Determinasyon } \\
\text { Katsayısı }\left(\mathbf{R}^{2}\right)\end{array}$ & \multicolumn{2}{|c|}{0.9804} & \multicolumn{2}{|c|}{0.9705} & \multicolumn{2}{|c|}{0.9771} & \multicolumn{2}{|c|}{0.9843} & \multicolumn{2}{|c|}{0.9642} & \multicolumn{2}{|c|}{0.9586} \\
\hline
\end{tabular}




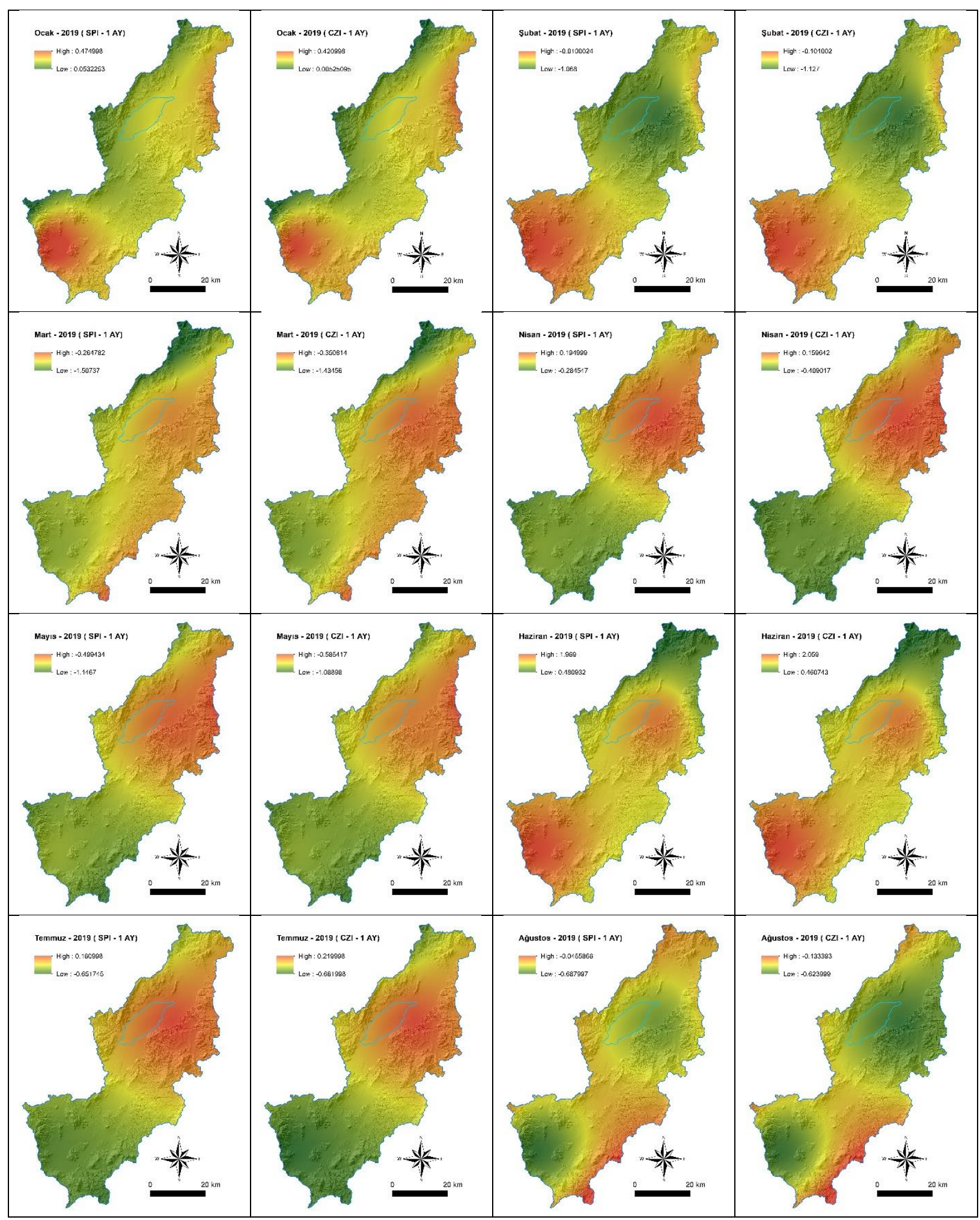

Şekil 9: Çalışma alanının SPI ve CZI yöntemleri kullanılarak hazırlanan aylık kuraklık haritaları 


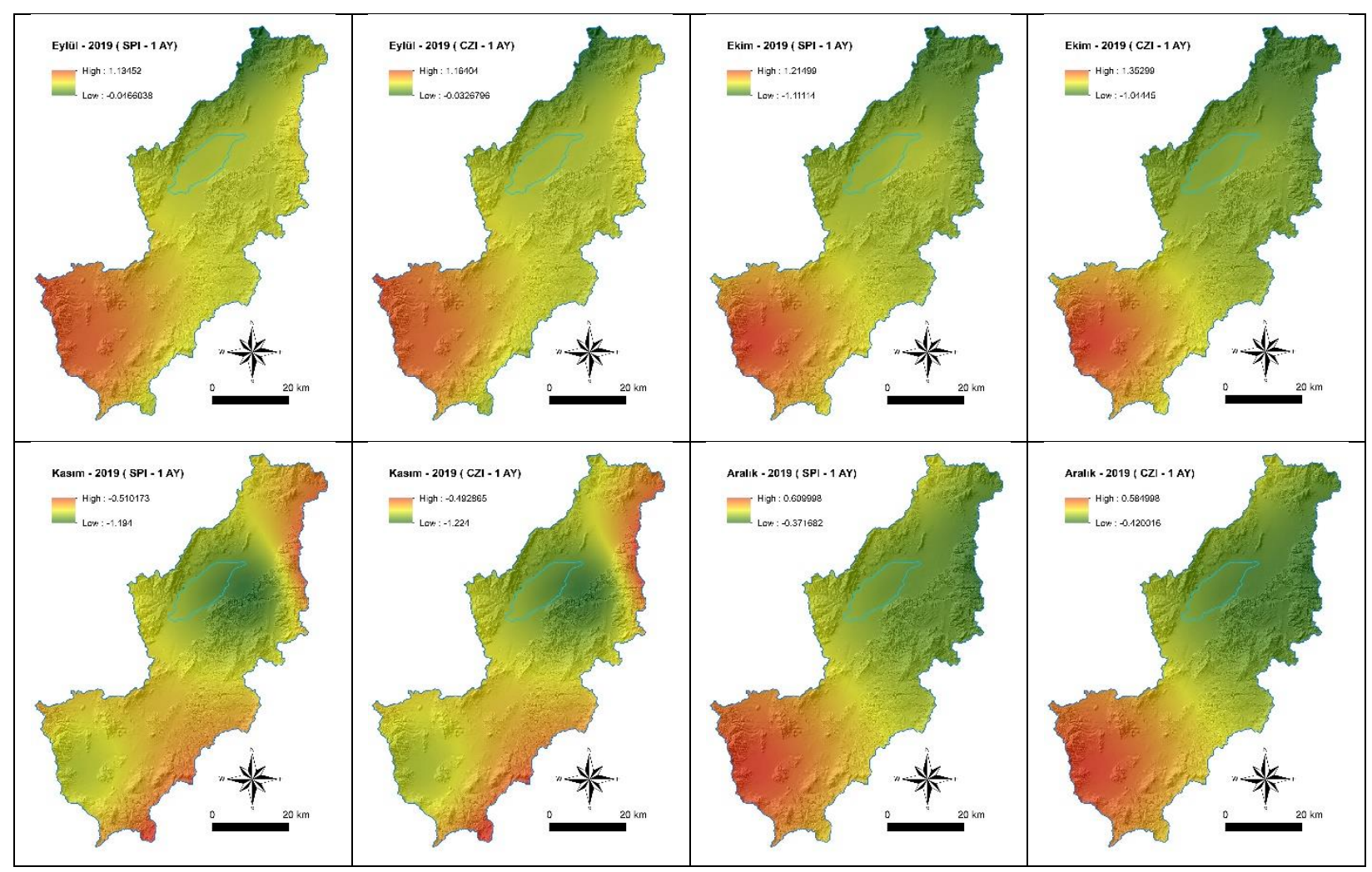

Şekil 9: Çalışma alanının SPI ve CZI yöntemleri kullanılarak hazırlanan aylık kuraklık haritaları (devam)

\section{Sonuç ve Tartışma}

Burdur Gölü Havzasına düşen yağış miktarında özellikle son yıllarda önemli miktarlarda azalma söz konusudur. Bu nedenle havza genelinde bazı dönemlerde şiddetli ve uzun periyotlu kuraklık yaşanmaktadır. Bu çalışmada havza genelinde standartlaştırılmış yağış indeksi ile Çin Z indeksi yöntemleri kullanılarak kuraklık analizleri yapıllmıştır. Ayrıca SPI ve CZI indeksleri arasındaki ilişkiler istatistiksel olarak ortaya konulmuştur. Bu kapsamda havza içerisinde bulunan ve gerekli ölçüm periyotlarına sahip olan Burdur ve Tefenni meteoroloji istasyonlarının yanı sıra havzanın yakınlarında bulunan Dinar, Isparta, Korkuteli ve Acıpayam meteoroloji istasyonlarına ait veriler kullanılmıştır.

Çalışma sonucunda elde edilen verilere göre, SPI ve CZI analizlerinden elde edilen indeks verilerinin değerlendirilmesinde zaman ölçeği arttıkça kurak ve yağışlı dönemler daha hassas olarak belirlenmiş, özellikle 12 ve 24 aylık zaman ölçeklerinde kurak ve yağışlı periyotları çok daha net olarak ortaya konulmuştur. Standartlaştırılmış yağış indeksi ile Çin Z indeksi yöntemleri ile yapılan kuraklık analizleri sonucunda elde edilen indeks değerleri arasındaki ilişkilerin belirlenebilmesi amacıyla yapılan lineer regresyon analizlerine göre iki yöntem arasındaki determinasyon katsayısı $\left(\mathrm{R}^{2}\right)$ değerlerinin 0.9586 ile 0.9843 arasında değiştiği belirlenmiştir. SPI ve CZI indeks değerleri arasındaki korelasyon katsayılarının ise Burdur DMI'de 0.9901, Tefenni DMİ'de 0.9851, Korkuteli DMI'de 0.9885, Isparta DMI'de 0.9821, Dinar DMİ'de 0.9820 ve Acıpayam DMİ'de ise 0.9791 olduğu ve her iki indeks arasında çok yüksek pozitif korelasyon olduğu tespit edilmiştir. Ayrıca meteoroloji istasyonlarına ait noktasal bazlı kuraklık indeks değerleri kullanılarak IDW enterpolasyon yöntemi ile havza bazlı alansal tematik kuraklık haritaları üretilmiştir. Söz konusu haritalarda kuraklığın zamansal ve konumsal değişimleri incelendiğinde SPI ve CZI yöntemleri ile elde edilen haritaların birbirlerine çok benzer olduğu belirlenmiştir. Bakanoğulları (2020b) tarafından yapılan çalışmada, sunulan çalışmaya benzer şekilde iki farklı kuraklık indeks yöntemi kullanılmış ve karşıllaştırılmıştır. Bunlar, Standartlaştırılmış Yağış Evapotranspirasyon İndisi (SPEI) ve Standartlaştırılmış Yağış İndisi (SPI) yöntemleri olup, yıllık SPI ve SPEI kuraklık indeksleri arasındaki determinasyon katsayısı $\left(\mathrm{R}^{2}\right) 0.977$ olarak belirlenmiştir. Aynı şekilde Mahmoudi (2019) ve Kassaye (2020) tarafından yapılan çalışmalarda da SPI ve CZI yöntemleri kullanılarak gerçekleştirilen kuraklık değerlendirmelerinde sonuçların birbirlerine yakın olduğu tespit edilmiştir. Bu çalışmada da SPI ve CZI yöntemleri kullanılarak yapılan kuraklık analizlerinde literatürde ki çalışmalara benzer olarak birbirlerine çok yakın sonuçlar elde edilmiştir.

Sonuç olarak Burdur Gölü Havzasında iklim değişikliğine bağlı olarak gelişen kuraklıkların karakterizasyonunun belirlenerek kuraklığın etkilerinin azaltılmasına yönelik eylem planlarının yapılması aşamalarında Standartlaştırılmış Yağış İndeksi ile Çin Z İndeksi yöntemlerinin birlikte kullanılmasından ziyade bu yöntemlerden sadece birinin tercih edilmesinin yeterli olduğu belirlenmiştir. 


\section{Kaynaklar}

Anisfeld S.C., (2010), Water Resources, Island Press, Washington, DC., 352ss.

Ataol M., (2010), Burdur Gölü Havzası İçin Yeni Bir Su Yönetim Modeli Önerisi, Doktora Tezi, Ankara Üniversitesi, Sosyal Bilimler Enstitüsü, Ankara.

Awchi T.A., Kalyana M.M., (2017), Meteorological drought analysis in northern Iraq using SPI and GIS, Sustainable Water Resources Management, 3(4), 451-463.

Bakanoğulları F., (2020a), Kırsal havzalarda kuraklı̆̆ı iki yöntem (SPEI ve SPI) kullanılarak belirlenmesi: Kumdere Havzası örneği, Türk Tarım ve Doğa Bilimleri Dergisi, 7(1), 146-156.

Bakanoğulları F., (2020b), SPEI ve SPI indisleri kullanılarak İstanbul-Damlıca Deresi Havzasında kuraklık şiddetlerinin analizi, Toprak Su Dergisi, 9(1), 1-10.

Byun H.R., Wilhite D.A., (1999), Objective quantification of drought severity and duration, Journal of Climate, 12(9), $2747-2756$.

Choi M., Jacobs J.M., Anderson M.C., Bosch D.D., (2013), Evaluation of drought indices via remotely sensed data with hydrological variables. Journal of Hydrology, 476, 265-273.

Çaldağ B., Şaylan L., Toros H., Bakanoğulları F., (2004), Drought Analysis in northwest Turkey, Agroenvironment 2004, 20-24 October, Udine, Italy, ss.169-179.

Dikici M., (2019), Asi Havzası'nda (Türkiye) kuraklık analizi, Doğal Afetler ve Çevre Dergisi, 5(1), 22-40.

Dogan S., Berktay A., Singh V.P., (2012), Comparison of multi-monthly rainfall-based drought severity indices, with application to semi-arid Konya closed basin, Turkey, Journal of Hydrology,70(471), 255-268.

Dracup J.A., Lee KS., Paulson Jr. EG., (1980), On the definition of drought, Water Resource Research, 16(2), $297-302$.

Gibbs W.J., Maher, J.V., (1967), Rainfall Deciles as Drought Indicators, Bureau of Meteorology Bulletin, 48, Melbourne, Australia.

İlker A., Terzi Ö., Şener E., (2019), Yağışıı Alansal Dağılımının Haritalandırılmasında Enterpolasyon Yöntemlerinin Karşılaştırılması: Akdeniz Bölgesi Örneği, Teknik Dergi, 30(3), 9213-9219.

İrvem A., Özbuldu M., (2019), Analysis of drought period with SPI for Muğla province of Turkey, Mustafa Kemal Üniversitesi Tarım Bilimleri Dergisi, 24 (Özel Sayı):142-148.

Jain V.K., Pandey R.P., Jain M.K., Byun H.R., (2015), Comparison of drought indices for appraisal of drought characteristics in the Ken River Basin, Weather and Climate Extremes, 8, 1-11.

Kassaye A.Y., Shao G., Wang X., Wu S., (2020), Quantification of drought severity change in Ethiopia during 1952-2017, Environment, Development and Sustainability, doi: 10.1007/s10668-020-00805-y.

Kendall M., Stuart A., (1977), The advanced theory of statistics, Vol. 1: Distribution Theory, 4th edition, C. Griffin, 484ss.

Kömüşçü A., Erkan A., (2006), Kuraklık ve Türkiye Açısından Genel Bir Değerlendirme, DMİ Genel Müdürlüğü Araştırma ve Bilgi İşlem Dairesi Başkanlığı, Ankara.

Köroğlu S., (2006), Farklı EnterpolasyonYöntemlerinin Hacim Hesabına Etkisinin Araştırılması, Yüksek Lisans Tezi, İstanbul Teknik Üniversitesi, Fen Bilimleri Enstitüsü, İstanbul.

Mahmoudi P., Rigi A., Kamak M.M., (2019), A comparative study of precipitation-based drought indices with the aim of selecting the best index for drought monitoring in Iran, Theoretical and Applied Climatology, 137(3-4), 3123-3138.

McKee T.B., Doesken N.J., Kleist J., (1993), The Relationship of Drought Frequency and Duration to Time Scales, 8th Conference on Applied Climatology, 17-22 January, Anaheim, California, ss.179-183.

McKee T.B., Doesken N.J., Kleist J., (1995), Drought monitoring with multiple time scales, 9th Conference on Applied Climatology, 15-20 January, Dallas, TX, USA, ss.233-236.

Mishra A.K., Singh VP., (2011), Drought modeling - a review, Journal of Hydrology, 403, 157-175

Morid S., Smakhtin V., Moghaddasi M., (2006), Comparison of seven meteorological indices for drought monitoring in Iran, International Journal of Climatology: A Journal of the Royal Meteorological Society, 26(7), 971-985.

Orhan O., (2014), Konya Kapalı Havzası 'nda Uzaktan Algılama ve CBS Teknolojileri İle İklim Değişikliği ve Kuraklık Analizi, Yüksek Lisans Tezi, Aksaray Üniversitesi, Fen Bilimleri Enstitüsü, Aksaray.

Palmer W.C., (1965), Meteorological Drought, U.S. Department of Commerce, Weather Bureau, Research Paper No: 45, Washington, DC., USA, 58ss.

Pamuk G., Özgürel M., Topçuoğlu K., (2004), Standart yağış indisi (SPI) ile Ege bölgesinde kuraklık analizi, Ege Üniversitesi Ziraat Fakültesi Dergisi, 41(1), 99-106.

Shukla S., Wood A., (2008), Use of a Standardized Runoff Index For Characterizing Hydrologic, Geophysical Research Letters, 35(2), L02405, doi:10.1029/2007GL032487.

Sırdaş S., (2002), Meteorolojik Kuraklık Modellemesi ve Türkiye Uygulaması, Doktora Tezi, İTÜ Fen Bilimleri Enstitüsü, İstanbul.

Sırdaş S., Şen Z., (2003), GAP Bölgesinde kurak dönem özelliklerinin araştırılması, III. Atmosfer Bilimleri Sempozyumu, 19-21 Mart, İstanbul, Türkiye, ss.305-317.

Şen Z., (2001), Kuraklık Kıranı Yuvarlak Masası Toplantısı, 20 Mart 2001, Ankara Hilton Oteli.

Şener E., Şener Ş., (2019), Meteorolojik kuraklı̆̆ın cŏgrafi bilgi sistemleri tabanlı zamansal ve konumsal analizi: Çorak Gölü Havzası (Burdur-Türkiye) örneği, Mühendislik Bilimleri ve Tasarım Dergisi, 7(3), 596-607.

TOB, (2018), Burdur Gölü Sulak Alan Revize Yönetim Planı Projesi Sonuç Raporu, Tarım ve Orman Bakanlığı, Doğa Koruma ve Milli Parklar Genel Müdürlüğü, Sulak Alanlar Şube Müdürlüğü, 322ss.

Thom H.C.S., (1966), Some Methods of Climatological Analysis. WMO Technical Note, 81, World Meteorological Organization, Geneva, Switzerland, 63ss.

Tsakiris G., Vangelis H.J.E.W., (2005), Establishing a drought index incorporating evapotranspiration, European water, 9(10), 3-11.

Tuna H., Malkoç F., Yılmaz Ö., (2009), Çoruh Havzasında SPI ile Kuraklık Analizi ve Çevresel Etkileri, Doğu Karadeniz Bölgesi Hidroelektrik Enerji Potansiyeli ve Bunun Ülke Enerji Politikalarındaki Yeri Forumu, Trabzon, ss.114-129.

Vicente-Serrano S.M., Beguería S., López-Moreno J.I., (2010), A multiscalar drought index sensitive to global warming: The standardized precipitation evapotranspiration index. Journal of Climate, 23, 1696-1718.

WMO, (1997), Extreme Agrometeorological Events, CagM-X Working Group, WMO/TD-No.836, Geneva, Switzerland, 182ss. 
WMO, (2016), Handbook of Drought Indicators and Indices, Integrated Drought Management Programme (IDMP), WMO-No. 1173, Geneva, Switzerland, 45ss.

Wambua R.M., Mutua B.M., Raude J.M., (2018), Detection of spatial, temporal and trend of meteorological drought using standardized precipitation index (spi) and effective drought index (edi) in the upper Tana river basin, Open Journal of Modern Hydrology, 8, 83-100.

Wilhite D.A., Glantz M.H., (1985), Understanding The Drought Phenomenon: The Role of Definitions, Water International, 10(3), 111-120.

Wilhite D.A., Svoboda M.D., (2000), Drought early warning systems in the context of drought preparedness and mitigation, Early warning systems for drought preparedness and drought management'in İçinde, (Wilhite D.A, Sivakumar M.V.K., Wood D.A., Eds.), Lisbon, Portugal, ss.1-21.

Willeke G., Hosking J.R.M., Wallis J.R., Guttman N.B., (1994), The National Drought Atlas, U.S. Army Corps of Engineers Institute for Water Resources Report 94-NDS-4, 587ss.

Wilson E.B., Hilferty M.M., (1931), The distribution of chi-square, Proceedings of the National Academy of Sciences of the United States of America, 17(12), 684-688.

Wu H., Hayes M.J., Welss A., Hu Q., (2001), An evaluation the standardized precipitation index, the China-z index and the statistical Z-Score, International Journal of Climatology, 21, 745-758. 